\title{
EUROPE'S WILD HEART - STILL BEATING? EXPERIENCES FROM A NEW TRANSBOUNDARY WILDERNESS AREA IN THE MIDDLE OF THE OLD CONTINENT
}

\author{
ZDENKA KřREOVÁ $1,2,3, *$ and HANS KIENER ${ }^{4}$ \\ ${ }^{1}$ Global Change Research Centre AS CR, v.v.i., Department of Biodiversity Research, Na Sádkách 7, 37005 České Budějovice, \\ Czech Republic \\ ${ }^{2}$ Institute for Environmental Studies, Faculty of Science, Charles University in Prague, Benátská 2, 12801 Prague 2, Czech Republic \\ ${ }^{3}$ Faculty of Science, University of South Bohemia, Branišovská 31, 37005 České Budějovice, Czech Republic \\ ${ }^{4}$ Bavarian Forest National Park, Freyunger Strasse 2, 94481 Grafenau, Germany \\ * Corresponding author: krenova.z@czechglobe.cz
}

\begin{abstract}
The face of Europe has been shaped by human civilization for centuries and wilderness did not only vanish from the continent's surface but also from humans' minds and experiences. However, there are still a few places left, which have remained more or less unmodified and have at least the potential for rewilding. Among them are the Šumava National Park and the neighbouring Bavarian Forest NP, which together create a unique forest zone in the middle of Europe susceptible to host and demonstrate natural forest dynamics and ecosystem processes. This is also a large and very important Natura 2000 area. Transboundary cooperation between both National parks has improved since 1990, when the former Iron Curtain Corridor was opened, and culminated by the project Europe's Wild Heart. The main goal of the project Europe's Wild Heart, which started in 2008, was to develop a transboundary wilderness area in the core zones of the two national parks - BFNP and ŠNP. The project area was 13,060 ha and a "life story" of this project is described in this paper.

A common "vision 2020" was signed where both parks committed among other things "to achieve a joint core area of about 15,000 ha with harmonized management principles, information services and monitoring networks to officially become the first and largest transboundary wilderness area in Central Europe". Unfortunately, the bark beetle outbreak which followed the Kyrill hurricane in 2008 and 2009 escalated the discussion about appropriate forest management in the ŠNP. Opponents of the national park principles, non-intervention and wilderness concept became more and more vocal. The situation escalated after the election in 2010 when the Green Party was replaced by conservatives (ODS - Civic Democratic Party) at the Czech Ministry of Environment. Clear cuttings were started in some former non-intervention parts of the ŠNP and hunting was again allowed in the core zone. Since then, both the management strategies and practical management measures in the ŠNP and BFNP have increasingly diverged.

Opponents of the wilderness concept from both countries took advantage of the situation and, currently, the project Europe's Wild Heart is put on ice in both countries. Benefits and challenges of the project Europe's Wild Heart are discussed at the end of this paper.
\end{abstract}

Keywords: wilderness, transboundary cooperation, national park, biodiversity, Natura 2000

\section{Introduction}

The face of Europe has been shaped by human civilization and the population density of the European continent is greater than others. Since our ancestors settled in the New Stone age, their natural surroundings have been changed in a continual process into cultivated landscapes, with expanding human settlements, whilst some areas have been exploited and devastated leaving practically no more space for wilderness. As Aldo Leopold, one of the well-known North American pioneers of wilderness protection, observed in 1935 at the end of a study trip through Europe: Wilderness did not only vanish from the continent's surface but also from humans' minds and experiences (Leopold 1935). However, there are still a few places left, which have remained more or less unmodified and have at least the potential for rewilding. The importance of wilderness for Europeans has been recognised and different activities have started for the protection of wilderness over the past few years (Kun 2013). An inventory has shown that no more than $1.5 \%$ of Europe can be classified as wilderness and as was predicted most of these areas occur in the boreal zone, mountains, and some rural areas (Fisher et al. 2010).

First of all mountains are the last wilderness refuge in the densely populated Central Europe. People have been coming to mountains for centuries (Küster 2000; Roebroeks 2006) but the intensity of human interventions has fluctuated in space and time and there were always some inaccessible areas, which were too far and too wild for temporally continuous settlements (Cronon 1996). These wild fragments (i.e., wilderness) served as refuges for disparate habitats and their biota was able to recolonize other parts of mountains in times of declining human impacts (e.g., Kuras et al. 2003). A chain of mountains rises along the Czech-Bavarian border in the heart of Europe and due to specific historical consequences a large forest, called Silva Gabreta in the past, still occurs there. It is the last remnant of the "Hercynian Forest of the Romans". The Bohemian Forest and Bavarian Forest (recent names of this area) together form the largest contiguous woodlands in Central Europe covering more than two million hectares. Up to the present day they have remained free of larger settlements and have not been dissected by roads to any great extent. 
Two national parks - the Bavarian Forest National Park (BFNP) in Germany and the Šumava National Park (ŠNP) in the Czech Republic protect the most valuable parts of this region and provide a unique opportunity to protect European wilderness, which is, in the European cultural context, also understood as a slightly modified and non-intervention zone located within a protected area where all management objectives are directed towards ecosystem protection and enhancing natural processes in the area. Newly wilderness is also defined as a non-intervention zone where management objectives of the IUCN categories I b and II meet. National parks have been recognised as very important areas for this new European wilderness concept (Šolar 2009).

When the Bavarian Parliament voted unanimously to establish the BFNP in 1969, the first National Park in Germany, it was thought that this project would probably generate urgently needed income for the local population through the creation of new jobs and the support of tourism in this poor region bordering on to the Iron Curtain. Similar reasoning also stimulated the establishment of ŠNP in 1991, immediately after the fall of the Iron Curtain. Since the establishment of the national parks, tourism in the adjoining rural communities has developed from its modest beginnings to a supporting pillar of employment and income. According to a recent study (Job et al. 2007) the BFNP is an important component of the regional economy. With 760,000 visitors per year the BFNP is the region's most frequented attraction. The share of tourism that takes place in the BFNP provides the region with an occupation equivalent to 940 people and with an additional 200 full-time jobs in the national park authority. Similar results can be observed also in the ŠNP, though hard data have not yet been collected.

\section{Geography of the area and natural conditions}

The Bavarian Forest and Šumava National Parks (BF and $\check{S}$ NP) are located between Prague (Czech Republic) and Munich (Bavaria, Germany), approximately $180 \mathrm{~km}$ from each of these two capitals. BF and ŠNP, located in the centre of this area, with its highest peaks Mt. Rachel $(1,453 \mathrm{~m})$ and Plechý $(1,379 \mathrm{~m})$, is a densely wooded landscape of great beauty, comprising crystal clear mountain streams, unspoiled marshlands, mires and bog woodlands, and abandoned mountain pastures at higher elevations. It is home and refuge for many endangered species of plants and animals. There are many elements of the northern boreal forest, and capercaillie (Tetrao urogallus), Ural owl (Strix uralensis), three-toed woodpecker (Picoides tridactylus) and other species have an important south-western outpost in the middle of the broad-leaved forest that dominates this part of the continent. In an area of more than 90,000 ha, BF and ŠNP today protect a representative sample of the Central European highlands and an important part of Europe's natural and cultural heritage. The parks have a fairly long common border, which accentuates the transboundary character of nature conservation, ecological corridors and connectivity.

Both national parks form the largest terrestrial Natura 2000 sites in both countries. Therefore, they play a significant role in the Natura 2000 network, the European network for the protection of the most endangered habitats and species. As the result of the common mapping project (Husslein and Kiener 2007) more than 25 Natura 2000 habitats have been recorded in this area; of them the following habitats are the most important:

- 9410 mountain spruce forests (ass. Piceion excelsae), - 7110 peat bogs (ass. Leiko-Scheuchzerion palustris), - 91D0 bog woodlands (ass. Dicrano-Pinion),

- 6230 mountain Nardus meadows (ass. Nardo-Agrostis tenuis).

The BFNP was the first protected forest in Central Europe affected on a large scale by the bark beetle outbreak following several wind throws. Since the 1980s the park has served as a pilot study area for Central Europe, from which management guidelines have been developed for commercial forests and strictly protected areas with a "benign neglect strategy" (Müller et al. 2010). Periodic windstorms and bark beetle outbreaks have been recognized as a natural phenomenon affecting this forest region for centuries. Scientific projects conducted both in the BFNP (Heurich 2009), and ŠNP (Čížková et al. 2011) reported strong natural regeneration of mountain spruce forests affected by bark beetle over the past several decades.

Insect outbreaks are one of several natural disturbances in forests. Like wildfires and windstorm events insect outbreaks create a substantial amount of dead wood and open up the tree canopy across large areas. Investigations of the effects of dead wood due to bark beetle infestation have revealed positive effects on the abundance of red-listed saproxylic beetles and other species. One species that requires forests in primeval condition, and is therefore rare, is the wood-inhabiting fungus with the nice-sounding name Antrodiella citronella. This species is mainly associated with boreal coniferous forests. In the BFNP large amounts of deadwood (about $200 \mathrm{~m}^{2} / \mathrm{ha}$; amounts known from primeval forests), allowed this fungus, which has barely survived in two remnants of pristine forests, to spread from these small relic populations to the whole national park within a radius of more than $30 \mathrm{~km}$ (Bässler and Müller 2010). The role of bark beetles in the predominant mountain spruce forest ecosystem is no longer considered to be a pest that has to be controlled or eradicated but a keystone species in the natural cycles of coniferous forest ecosystems (Müller et al. 2008) and more familiarly could be called the doorman to wilderness.

Today, dynamic processes rather than particular species or stages of development are the focus of protection efforts in national parks, as they are a basic characteristic of living systems and essential to biological evolution. 
In the course of time, the motto "Let nature be nature" has emerged from the BFNP's initial, indefinite concept. If we think this matter through accordingly, the concept of non-intervention leads us to the protection of wilderness.

Different forest management strategies have been applied along the borders over recent decades. A programme to combat bark beetles (Ips typographus) and cutting infected trees were standard management practices on the Czech side during the time when a non-intervention strategy had already been adopted in the BFNP. Šantrůčková et al. (2010) and Kindlmann et al. (2012) summarized the results of many scientific studies from the ŠNP documenting the excellent natural recovery of mountain ecosystems after bark beetle outbreaks, but unfortunately the implementation of non-intervention management in the ŠNP fluctuates. The zonation of the ŠNP and its management strategy has been changed without reflecting current scientific knowledge several times since the establishment of the ŠNP (Křenová and Hruška 2012). Furthermore, the acceptance of the wilderness concept fluctuates in time along with changing political climates, both in the region and the country.

A clear message about forest management in the $\mathrm{BF}$ and ŠNP was delivered by the Kyrill windstorm in January 2007 (Kiener and Křenová 2009a). A lengthy discussion about appropriate forest management in the ŠNP arose after the strong windstorm, when mountain spruce forests in the ŠNP were strongly affected and thousands of spruce trees were uprooted. In particular, open groves, where active cutting of bark beetle infected trees had been applied in previous years, were extensively damaged, and the lesson was learnt. The situation in the upper part of the mountains along the Czech-Bavarian border was crucial and cooperation and coordination of management practices were necessary and successful.

\section{Main milestones in developing transboundary cooperation}

Plans to protect the large forest landscape on the Czech-Bavarian border date back to the early 20th century, though they were never implemented, due firstly to the two World Wars and then to the Iron Curtain, which separated not just the political blocs during the Cold War but also the human and natural environment of Europe for half a century from 1945 to 1990. In 1969, the old wishes were at least partly fulfilled with the establishment of the BFNP, then measuring 13,300 ha. In 1991, the Czech Republic set aside the most valuable parts as a national park. The designation of 68,500 ha of the ŠNP was an important step towards the establishment of a large cross-border protected area of international significance. By virtue of the decision of the Bavarian Parliament to enlarge the BFNP by an additional 11,000 ha on 1 August 1997, a unique opportunity arose to safeguard a remarkable section of more than 90,000 ha of land as a natural landscape and ecological refuge that is unrivalled in Central Europe (Fig. 1).

The main partners involved in transboundary cooperation in BF and ŠNP are the Šumava National Park Authority, the Bavarian Forest National Park Authority, the Ministry of Environment of the Czech Republic, and

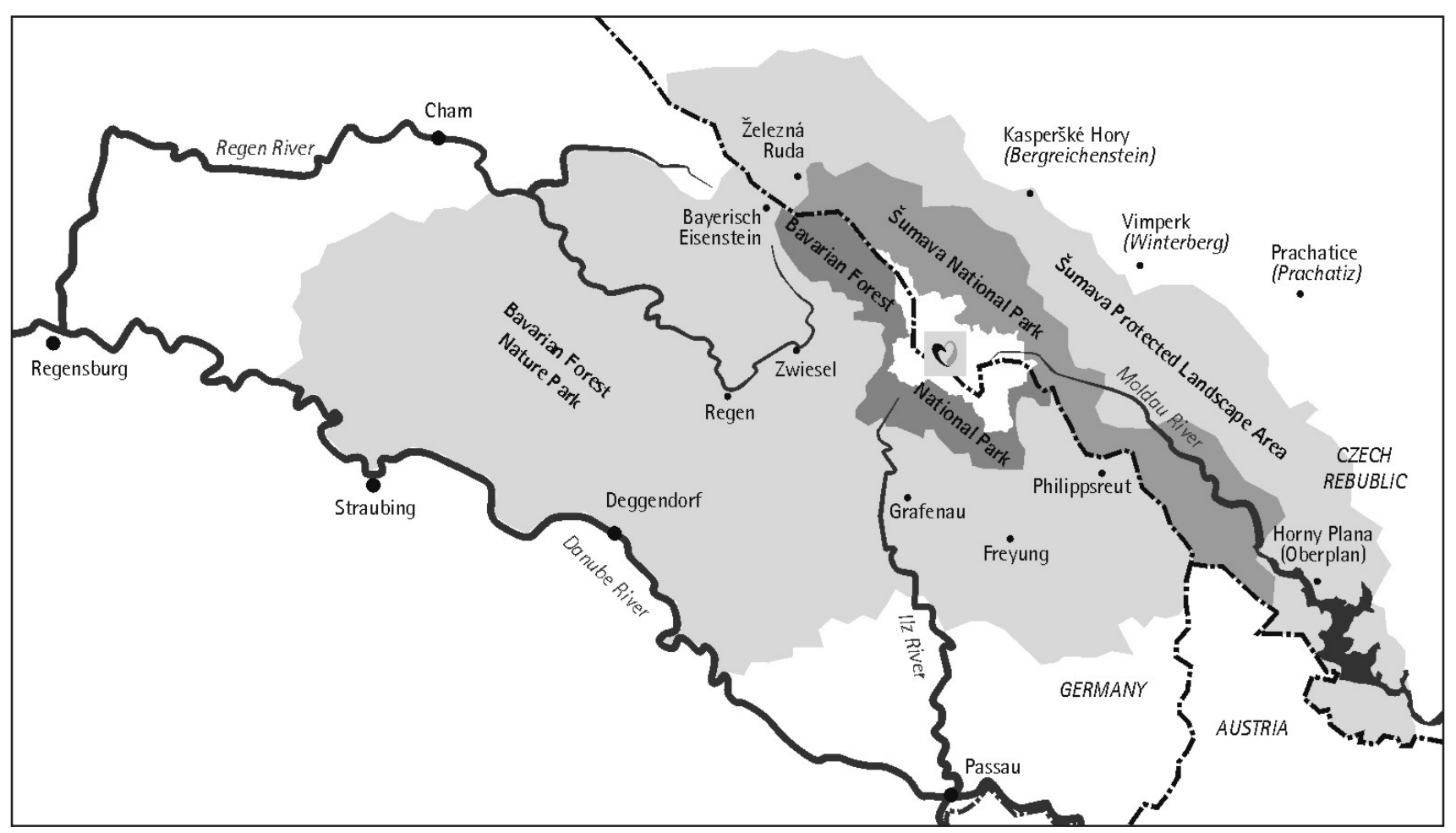

Fig. 1 Map of the Šumava National Park in the Czech Republic and the Bavarian Forest National Park in Germany. The Europe's Wild Heart area is in the middle, marked by the logo. 
the Ministry of Environment and Public Health of the State of Bavaria, which has been involved in transboundary cooperation since 2004 (until then the responsible authority was the Ministry of Agriculture and Forestry of the State of Bavaria).

With great enthusiasm, the two national park authorities established practical, though informal, collaboration from the very beginning in 1991. Since 1999, cross-border cooperation has been based on the Memorandum on Cooperation between the ŠNP and the BFNP, which was signed by the State Ministers responsible for the respective national parks. In the meantime, several supplementary protocols have been signed, e.g., regarding park management and new cross-border trails. In 2009, both parks agreed on common management guidelines for a transboundary wilderness area. Both parks have been official partners in several European funded projects (Interreg, Leader, and the German-Czech Future Fund).

In order to achieve the common objectives for this integrated area, cross-border cooperation has focused primarily on the following:

\section{First joint information centre}

An information centre was built at Bučina, one of the main points of entry to the ŠNP from the BFNP. This was the first joint project. Bilingual displays on the national park concept, the development of protected areas, landscape succession, national park regulations and, above all, visitor attractions are presented there.

\section{Transboundary public transport system}

In 1996, the two national parks were enhanced as a holiday area through the introduction of public transport systems. On the Bavarian side, "hedgehog buses" have been operating since May 1996, linking all the park's important visitor facilities and sites with the surrounding towns and villages. A public transport system was also established in the ŠNP in the same year. Both services use buses that run on low-emission natural gas or bio-gasoline fuels. The timetables of both public transport systems are coordinated and bilingual.

\section{Historical border train station becomes cross-border information office}

Following the formal inauguration of the restored historical border train station in Bayerisch Eisenstein/ Alžbětín by the two former State Ministers Miller (Bavaria) and Kužvart (Czech Republic), a cross-border information office was set up, offering bilingual information on both national parks and also the Šumava Protected Landscape Area and the Bavarian Forest Nature Park.

\section{Coordination and training of ranger services}

Ranger services are coordinated on both sides of the frontier in regular meetings. In addition to providing professional training for individual rangers, joint courses serve to foster personal acquaintances and understanding of the history and culture of the neighbouring country. In addition, a reference manual with the most important facts and information on both national parks was prepared in the form of a joint bilingual ranger handbook.

\section{Successful reintroduction of the Ural owl}

Twenty-five years of experience have shown that efforts to re-introduce the Ural owl were boosted considerably, thanks to the decision to initiate similar projects not only in the ŠNP but also in the nearby forest areas of Austria. This is a basic prerequisite for guaranteeing the development of a sustainable Ural owl population through an international management programme (Müller et al. 2007).

\section{Restoration of anthropogenically disturbed habitats}

An artificial drainage channel in the area of a valuable peat bog that extended across the state border was returned to nature in the core zone of both national parks in the summer of 2005.

\section{Junior Ranger programmes, international youth camps and Czech-German youth forum}

Several times in the past, and most recently in 2012, young people from the national park region were given the opportunity to explore the BF and ŠNP as part of a cross-border camping programme with young people from the partner Saxon Switzerland National Park and the Šumava and Bohemian Switzerland National Parks.

\section{Natura 2000 management planning}

BF and ŠNP are part of a uniform natural landscape that has no regard for political boundaries. Measures to protect endangered and rare habitats and species should ideally be designed on a large-scale basis and in this case, in a cross-border fashion. With this in mind, both national park authorities have been successfully working together on a project promoted by the EU (Interreg III A) to establish Natura 2000 management plans that include cross-border coordination. Within the framework of this project a bilingual brochure was published 
in September 2007 (Husslein and Kiener 2007). An international colloquium of scientists and protected areas managers was jointly hosted by Šumava NP and the Bavarian Forest NP in January 2009 (Husslein et al. 2009). Sixty participants from 12 EU states discussed the appropriateness of non-intervention management for protected areas and Natura 2000 sites, which was excellent for setting the context of transboundary collaboration in Europe's Wild Heart.

\section{LTSER platform and the scientific journal Silva Gabreta}

As permanently protected ecosystems in a process of near-natural development, both national parks were found to be extremely attractive control areas for ecosystem research (Heurich et al. 2010). During the last ten years, increasing numbers of research and monitoring projects have been operated on a transboundary basis. The main focus is on ecosystem processes such as natural disturbances and spruce bark beetle outbreaks, changes in water regimes and species diversity in response to climate change. Changes in ecosystem services and better awareness of national parks among the public have been emerging as topics for socio-economic studies. A joint Czech-Bavarian LTSER (Long-term socio-ecological research) platform Silva Gabreta has been launched. The same name, Silva Gabreta, is used for the international scientific journal that has been published since 1996.

\section{GPS lynx and deer telemetry}

The most successful common research project was GPS lynx and deer telemetry. The primary focus was to investigate across borders how the lynx uses its habitat in its current centre of activity in transboundary area Eastern Bavaria / South-West Bohemia and to determine the role of the species in the mountain forest ecosystem (deer-lynx, predator-prey relationship) on both sides of the border. The aim was also to break new ground in lynx research based on the results of satellite-supported deer telemetry (Heurich et al. 2011, 2012).

It is clear that in the first decade of cooperation (since establishment of the ŠNP), there were many spontaneous activities such as bilingual information facilities, student exchanges and ranger service cooperation. After signing of the Memorandum in 1999, significant transboundary cooperation focusing on the main issue of nature conservation began. Ten years later, we could assume that there were many positive results indicating the strengths and bringing broad benefits for the transboundary area (Ahokumpu and Šolar 2009). These included Natura 2000 sites and their management, understanding of the importance of the cross border perspective of nature protection and research, joint work of rangers, the Junior Ranger programme and environmental education. Also many common social and cultural events had been organised (e.g., film festival NaturVision or the threeyear project the Glass Ark, Eisch 2005) and national parks employees, local partners, NGOs, trainees, and volunteers of both countries were involved in many joint activities.

After years of successful and trusting cooperation a common vision 2020 was signed where both parks committed among other things "to achieve a joint core area of about 15,000 ha with harmonized management principles, information services and monitoring networks to officially become the first and largest transboundary wilderness area in Europe". In 2009 both parks were officially certified "Transboundary Parks" for their exemplary cooperation in several fields.

In 2009 the ŠNP decided to join the application of the BFNP for the European Diploma of Protected Areas. The BFNP had held the Diploma since 1986, and a joint application would add to the value of the transboundary collaboration. There were two main stimuli for this decision. Firstly, for the recognition that the Diploma would have given to the wild nature of the ŠNP and a periodic review of the protection to ensure that a state of wild nature was being maintained. Secondly, it would have brought the ŠNP into line with the BFNP. Experts visited both NPs in July 2010 and reported (Gallant 2010) that:

\footnotetext{
The Šumava NP forms with the neighbouring Bavarian Forest NP a unique forest zone in the middle of Europe susceptible to host and demonstrate natural forest dynamics and ecosystem processes .... Recognizes however that the current local and national political climate in the ŠNP does not offer sufficient guarantee regarding the long term management and the preservation of the park and that some essential management instruments are missing.
}

The experts recommended postponing the award or awarding the Diploma to the ŠNP until the following conditions were met: new zonation, 10 -year management plan respecting recommendations of international experts (IUCN, Ramsar etc.), and guarantees of cooperation with the BFNP. In March 2011, before the final meeting of the Group of specialists for the European Diploma of protected areas, the Czech Ministry of Environment (the Green Party was replaced by conservatives [ODS - Civic Democratic Party] after the election in 2010) withdrew the application of the ŠNP for the Diploma.

Since then, both the management strategies and practical management measures in the ŠNP and BFNP have increasingly diverged.

\section{Project "Europe's Wild Heart"}

A large part of this border region used to be a part of the Iron Curtain corridor. A specific land-use caused by 
the military regime during the Communist era strictly protected the Czech part of this area from most human interventions. Also large areas of the BFNP along the state border belong to those least influenced by human activities and many rare and endangered species have thus survived. The high natural values and importance of this area were known for decades but different political constitutions limited the coordination of nature protection. It can now be assumed that in BF and ŠNP, where the Iron Curtain once separated man and nature, wilderness is reawakening.

The main goal of the project Europe's Wild Heart, which started in 2008, was to develop a transboundary wilderness area in the core zones of the two national parks - BFNP and ŠNP. The project area was 13,060 ha; of which 5,797 ha in the BFNP and 7,263 ha in the ŠNP (Fig. 2). The BFNP is listed as a protected area with the status of IUCN Protected Area Category II (www.wdpa .org) and the Bavarian part of the Europe's Wild Heart area was located in the core zone of BFNP (= "naturzone"), in which non-intervention management has been applied since the 1980s. Hunting is not allowed and public access is regulated both in the breeding seasons of the most important species (e.g. capercaillie, hazel grouse, woodpeckers, lynx) and in the most sensitive habitats (e.g. peat bogs, marshlands, screes). The ŠNP is also listed as a protected area of the IUCN Protected Area Category II (www.wdpa.org) but the current zonation of this $\mathrm{NP}$ is very fragmented (for more detail see Křenová and Hruška 2012). The Czech part of the Europe's Wild Heart area was located in the non-intervention part of the ŠNP, where no trees have been harvested since 1997; water regime restoration projects (i.e. peat bogs renaturisation, Bufková et al. 2010) were applied during the last decade, and from which hunting was excluded in 2008. More than half of this wilderness area overlapped with the strictly protected nature reserves of the Modravské slatě mires (3,615 ha, established in December 1989), which is listed as a protected area of the IUCN Protected Area Category Ia (www.wdpa.org). For the Europe's Wild Heart project the wilderness area is understood as a large area of high biological value and intactness, which is mostly undis-

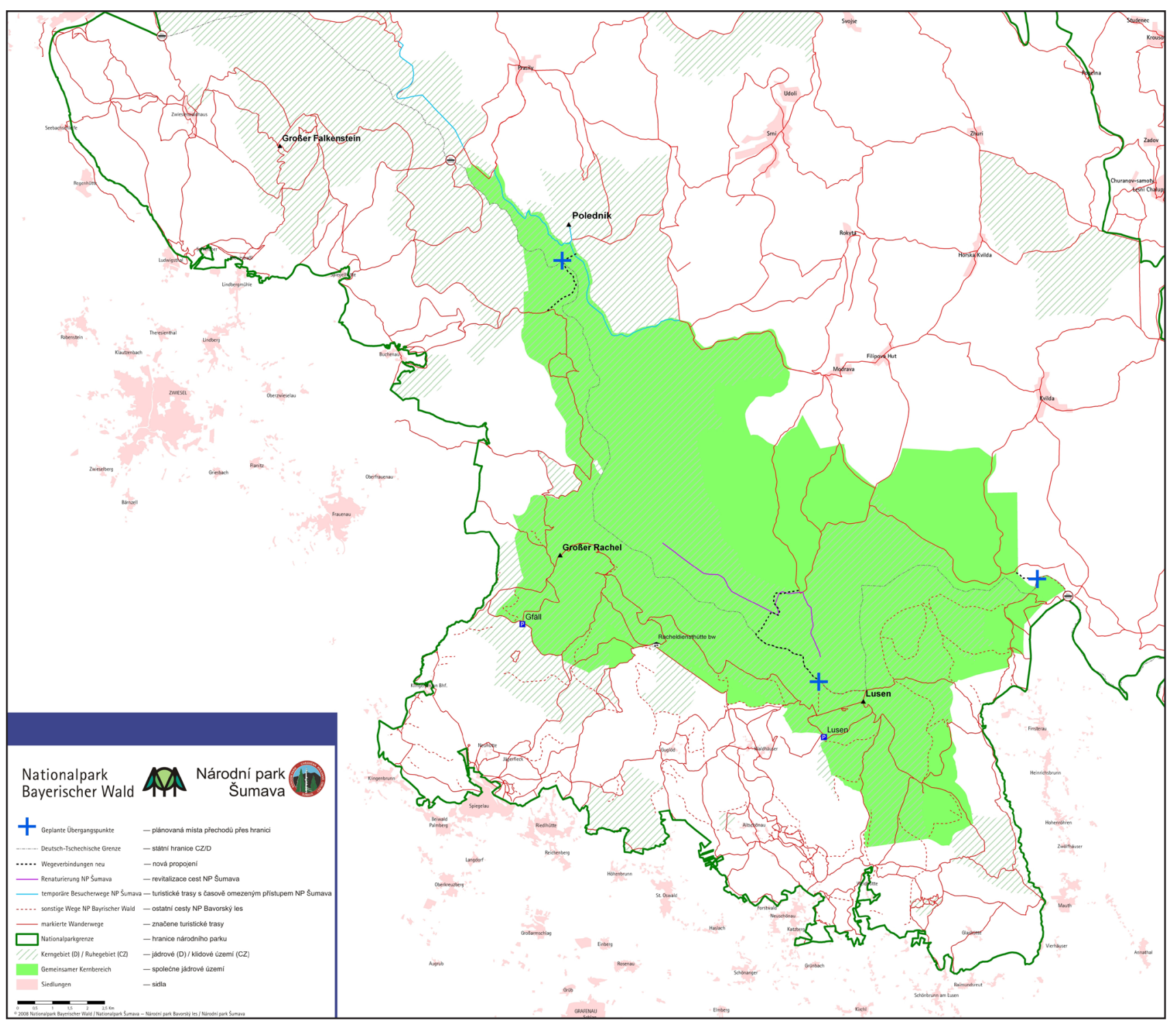

Fig. 2 The Europe's Wild Heart area. 
turbed by man, roadless and without other industrial infrastructure or permanent habitation, and where extractive activities are not allowed. Visitor access is permitted on certain hiking trails and guided tours are preferred. Scientific research is permitted but no manipulative experiments are allowed. Guidelines for uniform manage- ment of the united core zone were adopted (Křenová and Kiener 2009) and the project's milestones are listed in Table 1. The project (Meyer et al. 2009) has been jointly presented at several international conferences, including the World Wilderness Congress (WILD9) in Merida, Mexico (Kiener and Křenová 2009b).

Table 1 Europe's Wild Heart - milestones chronology.

\begin{tabular}{|c|c|c|}
\hline Date & Activity & More info / outputs \\
\hline \multicolumn{3}{|l|}{2008} \\
\hline 2008, March 3 & $\begin{array}{l}\text { The first meeting of BFNP \& SNP directors about a common core zone and the } \\
\text { Schengen Treaty system }\end{array}$ & \\
\hline 2008, May 28 & CBD Conference in Bonn - presentation of the Europe's Wild Heart project & \\
\hline 2008, March-May & Logo and flyers about the Europe's Wild Heart project were prepared & \\
\hline 2008, June-August & Guided tours to the Europe's Wild Heart area & \\
\hline 2008, September 18 & $\begin{array}{l}\text { Bav. and CZ Ministers of Environment met in Bayerische Eisenstein to agree } \\
\text { on a common core zone and new transboundary trails }\end{array}$ & \\
\hline 2008, October-December & $\begin{array}{l}\text { Common management guidelines for the Europe's Wild Heart project were } \\
\text { prepared }\end{array}$ & Křenová and Kiener 2009b \\
\hline 2008, November & $\begin{array}{l}\text { A new DVD with music \& photos presenting the Europe's Wild Heart area was } \\
\text { published }\end{array}$ & \\
\hline 2008, December 10 & $\begin{array}{l}\text { Lunch Conference for EC, DG Environment, Brussels - presentation } \\
\text { of the Europe's Wild Heart project }\end{array}$ & \\
\hline \multicolumn{3}{|l|}{2009} \\
\hline 2009, January 25-28 & $\begin{array}{l}\text { The appropriateness of non-intervention management for protected areas } \\
\text { and Natura } 2000 \text { sites: International colloquium of researchers and managers } \\
\text { of protected areas and Natura } 2000 \text { sites in Srni, ŠNP }\end{array}$ & Husslein et al. 2009 \\
\hline 2009, March 11 & Wilderness Workshop in St. Oswald, BFNP & \\
\hline 2009, April 6-13 & $\begin{array}{l}\text { The Czech Ecological Society Annual Conference, Ostrava, CZ - common LTSER } \\
\text { platform presentation }\end{array}$ & \\
\hline 2009, April-June & $\begin{array}{l}\text { Memorandum of the Czech and Bavarian Ministers of Env. about new } \\
\text { transboundary trails in the Europe's Wild Heart area }\end{array}$ & \\
\hline 2009, May 27-28 & $\begin{array}{l}\text { Prague Wilderness Conference "Protection and Restoration of Wilderness } \\
\text { and Large Natural Habitat Areas" - presentation of the Europe's Wild Heart project }\end{array}$ & \\
\hline 2009, May 28-30 & A post-conference field trip to the Europe's Wild Heart area & \\
\hline 2009, May 31 - June 5 & The film team from Brussels came to make the film "Wilderness in Europe" & \\
\hline 2009 , June 5 & $\begin{array}{l}\text { Exhibition on Transboundary Cooperation, Bad Windshei, Germany - presentation } \\
\text { of the Europe's Wild Heart project }\end{array}$ & \\
\hline 2009, June 8 & Wilderness Workshop in Kvilda, ŠNP & \\
\hline 2009, June $21-24$ & $\begin{array}{l}\text { A final meeting for Europarc Transboundary certification process; directors } \\
\text { of both NPs signed the Vision } 2020\end{array}$ & Ahokumpu and Šolar 2009 \\
\hline 2009, August & 2-day transboundary guided tours to the Europe's Wild Heart area & \\
\hline 2009. September $1-5$ & $\begin{array}{l}\text { 2nd European Congress of Conservation Biology, Prague - presentation } \\
\text { the outputs from the colloquium about non-intervention and Natura } 2000\end{array}$ & \\
\hline 2009, 0ctober 8-10 & "Nachhaltig Wild ..." the artist exhibition in Haus zur Wildnis, BFNP & \\
\hline 2009, November 6-13 & $\begin{array}{l}\text { WILD9 = Wilderness Congress in Merida, Mexico - presentation of transboundary } \\
\text { importance of the Europe's Wild Heart project }\end{array}$ & Kiener and Křenová 2009a \\
\hline \multicolumn{3}{|l|}{2010} \\
\hline 2010, February-May & A new web page of the Europe's Wild Heart project was published & $\begin{array}{l}\text { http://www.wildheart } \\
\text { ofeurope.eu }\end{array}$ \\
\hline 2010, November 17 & $\begin{array}{l}\text { "Kabinet Havel" = public discussion in the Arch Theatre, Prague, about wilderness } \\
\text { in Central Europe; the Open letter to the Czech Prime Minister and other politicians }\end{array}$ & $\begin{array}{l}\text { http://www.ceskavize.cz } \\
\text { /news/kabinet-havel } \\
\text {-divoke-srdce-evropy/ }\end{array}$ \\
\hline
\end{tabular}


The bark beetle outbreak which followed the Kyrill hurricane in 2008 and 2009 escalated the discussion about appropriate forest management in the ŠNP. Opponents of the national park principles, non-intervention and wilderness concept became more and more vocal. Political leaders, who came to their positions after the Czech Parliament Election in summer 2010, have preferred traditional forestry practices (i.e., clear cutting of bark beetle infected trees, artificial planting of young trees) in the management of the ŠNP. The main strategy of the ŠNP was changed and the top management of the ŠNP, including the director, were replaced. Since 2010 clear cuttings were started in some former non-intervention parts of the ŠNP and hunting was again allowed in the core zone. A new ŠNP Act, which was prepared by the Ministry of Environment in 2012, proposed a reduction in non-intervention area in the ŠNP, several new trails in capercaillie breeding areas and opening up of the ŠNP area for different developmental activities, including building new ski lifts and ski slopes. Understandably, in circumstances that threaten the very essence of nature protection in the ŠNP, but also in the neighbouring BFNP, most of the common cross-border activities aimed at the protection of wilderness ceased.

Opponents of the wilderness concept from both countries took advantage of the situation. Drifting apart in the crucial management approach and conservation goals together with a lack of cooperation between the BFNP and ŠNP authorities created conditions favourable for the emergence of half-truths and various myths. One of the first came already in 2010 when several local politicians strongly fought against Resolution \#32 from WILD9 stating that the Europe's Wild Heart area fulfilled all the prerequisites of a de facto wilderness area and should be placed quickly by lawmakers under de jure status as IUCN Protected Area Category 1b. Unfortunately local politicians did not understand that reclassification wouldn't have tightened the conservation regulations, but could have brought interesting opportunities for local development. None of the competent persons were prepared or courageous enough to explain this and advocate implementation of the Resolution. Currently, the Europe's Wild Heart project is on ice in both countries.

However, even in 2010, on 17th November, on the 21st anniversary of the Velvet Revolution, a Cabinet Havel meeting was held at the Archa Theatre in Prague to discuss the future of European wilderness, and in particular the transboundary core wild land area in the Šumava and Bavarian Forest NPs. The Open Letter sent subsequently to the President of the European Parliament, the EU Commissioner for the Environment, the German Chancellor, and the Prime Minister of the Czech Republic was inspiring, as was the idea of and execution of the discussion relating the European wilderness concept to cultural contexts. The signatories to the letter were ready to help and support the European and national authorities in preparation of essential documents for declaration of the first Central European Wilderness Area - Europe's Wild Heart.

\section{Conclusions: Benefits and challenges}

Much has been learnt during twenty years of cooperation, including many lessons from both nature and humanity as well as in communication. The examples listed above illustrate the wide range of successful BF and ŠNP cooperation, which culminated in a proposal to establish the first transboundary wilderness area in Central Europe.

But there are also some already prepared but untapped opportunities. Firstly, local tourism operators and other stakeholders haven't yet recognized the marketing opportunities of Europe's Wild Heart project for their business and local development. Secondly, the establishment of a new research and training centre (RTC) that was planned for a former military base in Kvilda, a village in the centre of the ŠNP, has been blocked. The plans for the building reconstruction were already prepared but the ŠNP Authority is no longer interested in the project. Moreover, the contacts between the scientific community and the ŠNP Authority are not as warm as they used to be. At present we have to conclude that a unique opportunity to use EU funds for rebuilding houses and inviting scientists and students from Czech and German universities to inhabit the areas where soldiers maintained the borders of the Iron Curtain just twenty years ago has been missed. The plans were ambitious but realistic. We believed that newly found interest and enthusiasm could replace militarism and worries about war. Visitors, local people and schoolchildren could have been warmly welcomed at this RTC to enjoy new experiences with wild nature, wilderness and the research projects operating there. Also local people could have used the benefits of this RTC (e.g. very good internet connection, cooperation with local restaurants, accommodation, tourism operators). The platform of the RTC could have provided us all with access to a New Europe, where good things for nature are recognized as good things for people and vice versa.

The first challenges for cooperation under the umbrella of the common project Europe's Wild Heart appeared already in 2008 when the Schengen Treaty came into effect, allowing free travel across European borders. In anticipation of the demands of local communities and tourism, the administrations of the BF and ŠNP came together to prepare joint management guidelines for $\mathrm{Eu}$ rope's Wild Heart (Křenová and Kiener 2009b), the core area of the national parks. In June 2009, this cooperation resulted in a joint system of wilderness trails that was agreed upon and officially marked for publication. 
Unfortunately the Memorandum of Understanding concerning the transboundary trails was never completely fulfilled by the Czech partners. Restoration activities such as removing of old roads and water regime restoration were jointly agreed by both partners to compensate for new human disturbances in the core zone, but these were never implemented by the Czech partners. Today there is increasing political pressure to open new transboundary trails (more than were originally agreed) but it is clear that several negative effects on many protected species and habitats (including Natura 2000 species and habitats) cannot be avoided without appropriate measures to compensate. This situation is also illustrative of a loss of confidence.

After a couple of years we learnt that the main obstacles to transboundary cooperation and the protection of wilderness are not just economic differences in the regions or language barriers, but above all different policies and laws. The biggest threat for transboundary cooperation, and of course to the joint project Europe's Wild Heart, is political instability in the Czech Republic. Unfortunately, the management strategy of the ŠNP is not yet stable; political upheaval and development pressures seriously threaten the future of the National Park.

With our recent experiences from this transboundary region we believe that the greatest challenge to follow nature and open borders is in our minds. We believe that by respecting all our neighbours (Czechs, Germans, big and small animals, plants, trees, and other creatures) we can deepen not only our knowledge but also our common understanding and reverence - both for natural and human diversity. And with this understanding, we can share responsibility for our common wilderness heritage and hope that the project Europe's Wild Heart will survive its current crisis and that its heart will start beating properly again.

\section{Acknowledgements}

We thank friends and colleagues from different state and non-government organisations for inspiring discussions and sharing their experiences with implementation the wilderness ideas in various parts of the World. We are grateful to many our colleagues from BF and ŠNP, political representatives, friends from universities and NGOs, and many common people for their courage to support the wilderness ideas in both better and worse times. Specifically, we would like to thank Václav Hraba for the project Europe's Wild Heart nice logo and designing the project printed materials, Till Mayer for his never ending enthusiasm for wilderness, and Tomás Mozga for organizing the Kabinet Havel discussion. We thank also very much Richard Blackman for improving the article language and two referees who made many useful comments. This work was supported by the grant No. CZ.1.05/1.1.00/02.0073 of the MSMT.

\section{REFERENCES}

Ahokumpu A, Šolar M (2009) Verification report for the Bavarian Forest National Park, Germany and Šumava National Park, Czech Republic on the application for the EUROPARC certificate: Transboundary Parks - Following Nature's Design. Ms. Depon. In: Grafenau, Germany.

Bufková I, Stibal F, Mikulášková E (2010) Restoration of drained mires in the Šumava National Park, Czech Republic. In: Likens G, Eiseltová M (eds) Restoration of lakes, streams, floodplains, and bogs in Europe: principles and case studies, Springer, pp 331-354.

Fisher M, Carver S, Kun Z, McMorran R, Arrell K, Mitchell G (2010) Review of Status and Conservation of Wild Land in Europe. University Leeds, UK.

Cronon W (1996) The trouble with wilderness: or, getting back to the wrong nature. Environ Hist 1: 7-28.

Čížková P, Svoboda M, Křenová K (2011) Natural regeneration of acidophilus spruce mountain forests in non-intervention management areas of the Šumava National Park - the first results of the Biomonitoring project. Silva Gabreta 17: 19-35.

Eisch S (2005) Glasarche in Waldmeer: Dokumentation einer Reise durch den Bayerische Wald und die Šumava / Skleněná archa v moři lesů: Zpráva o jedné cestě Bavorským lesem a Šumavou. Kartenhaus Kollektive Regensburg.

Gallant P (2010) Sumava National Park (Czech Republic) Application. Expert report. Strassburg. Available on: https://wcd .coe.int/com.instranet.InstraServlet?command=com.instranet .CmdBlob Get\&InstranetImage $=1777237 \&$ SecMode $=1 \&$ DocId $=1701080 \&$ Usage $=2$.

Heurich M (2009) Progress of forest regeneration after a large-scale Ips typographus outbreak in the subalpine Picea abies forests of the Bavarian Forest National Park. Silva Gabreta 15: 49-66.

Heurich M, Beudert B, Rall H, Křenová Z (2010) National Parks as Model Regions for Interdisciplinary LTER: The Bavarian Forest and Šumava National Parks Underway to Transboundary Ecosystem Research, pp 327-344. In: Müller F (ed.) Long-Term Ecological Research. Between Theory and Application. Springer.

Heurich M, Baierl F, Günther S, Sinner KF (2011) Management and conservation of large mammals in Bavarian Forest Nationalpark. Silva Gabreta 17: 1-18.

Heurich M, Möst L. Schauberger G, Reulen H, Sustr P, Hothorn T (2012) Survival and causes of death of European Roe Deer before and after Eurasian Lynx reintroduction in the Bavarian Forest National Park. Eur J Wildlife Res 58: 567-578.

Hußlein M, Kiener H (eds) (2007) Natura 2000 - Europas Wildes Herz / Divoké Srdce Evropy, Natura 2000 bilingual brochure. Grafenau/Vimperk.

Husslein M, Kiener H, Křenová Z, Šolar M (eds) (2009) The appropriateness of non-intervention management for protected areas and Natura 2000 sites. Srni Conference Report. Grafenau/ Vimperk.

Job H, Mayer M, Woltering M, Müller J, Harrer B, Metzler D (2007) Die Destination Nationalpark Bayerischer Wald als regionaler Wirtschaftsfaktor (Nationalpark Bayerischer Wald Wissenschaftliche Reihe, Sonderheft). Grafenau.

Kiener H, Křenová Z (2009b) Europe’s Wild Heart - New transboundary wsilderness in the middle of the Old Continent. In: Watson A, Murrieta-Saldivar J, McBride B (eds) The symposium on science and stewardship. The WILD9 Congress Proceedings, pp 65-71.

Kiener H, Křenová Z (2009a) Europe’s Wild Heart and Lecture after Kyrill. In: Husslein M, Kiener H, Křenová Z, Šolar M (eds) The appropriateness of non-intervention management for protected 
areas and Natura 2000 sites. Srni Conference Report. Grafenau/ Vimperk 2009, pp 24-27.

Kindlmann P, Matějka K, Doležal P (2012) Lesy Šumavy, lýkožrout a ochrana prírody. Karolinum, Praha.

Křenová Z, Hruška J (2012) Proper zonation - an essential tool for the future conservation of the Šmava National Park. Eur J Environ Sci 2: 62-72.

Křenová Z, Kiener H (2009) Společné jádrové ứzemí Národních parků Šumava a Bavorský les - Divoké srdce Evropy / Gemeinsamer Kernbereich der Nationalparke Šumava und Bayerischer Wald - Europas wildes Herz (bilingual common management guidelines). Grafenau/Vimperk.

Křenová Z, Kiener H (2011) Europe's Wild Heart - Responsibility for Europe. In: Vasilijevic M, Pezold T (eds.) Crossing Borders for Nature. European examples of transboundary conservation. IUCN. Gland, Switzerland and Belgrade, Serbia, pp 42-45.

Kun Z (2013) Wilderness at the edge of survival in Europe. Eur J Environ Sci, in press.

Küster H (2000) Prehistoric cultures and the development of woodlands. In: Agnoletti A, Anderson S (eds) Methods and approaches in forest history. CABI Publishing, UK, pp 215-220. Leopold A (1935) Why the Wilderness Society? Living Wilderness 1: 6 .
Meyer T, Kiener H, Křenová Z (2009) Wild Heart of Europe. Int J Wilderness 15: 33-40.

Müller J, Scherzinger W, Moning C (2007) European Ural Owl workshop. National Park Proceedings, Issue 8. Grafenau.

Müller J, Bußler H, Goßner M, Rettelbach T, Duelli P (2008) The European spruce bark beetle Ips typographus (L.) in a national park - from pest to keystone species. Biodivers Conserv 17: 2979-3001.

Müller J, Noss RF, Bussler H, Brand R (2010) Learning from a "benign neglect strategy" in a national partk: Response of saproxylic beetles to dead wood accumulation. Biol Conserv 143: 2559-2569.

Roebroeks W (2006) The human colonisation of Europe: where are we? J Quaternary Sci 21: 425-435.

Šolar M (2009) The New Wilderness Model in the European Context. In: Husslein M, Kiener H, Křenová Z, Šolar M (eds) The appropriateness of non-intervention management for protected areas and Natura 2000 sites. Srni Conference Report. Grafenau/Vimperk 2009, pp 16-17.

Šantrůčková $H$, Vrba J, Křenová Z, Svoboda $M$, Benčoková A, Edwards M, Fuchs R, Hais M, Hruška J, Matějka K, Rusek J (2010) Co vyprávějí šumavské smrčiny. [The Story of Mountain Spruce Forests in the Sumava Mts]. NPŠ, Vimperk. In Czech. 